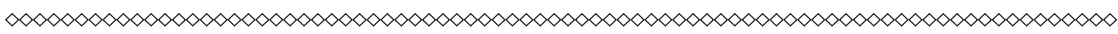

\title{
АКТУАЛЬНІ ПРОБЛЕМИ МІЖНАРОДНОГО ПРАВА
}

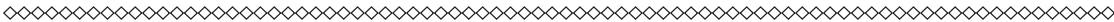

DOI https://doi.org/10.32837/app.v0i64.198

УДК 341.229: 347.85

Короткий T. P. * (НАУ)

ORCID ID: https://orcid.org/0000-0003-3201-4610

\section{МІЖНАРОДНЕ МОРСЬКЕ ПРАВО В КОСМІЧНУ ЕРУ: ПРАВО ТА ЕКОЛОГІЯ}

\section{INTERNATIONAL MARITIME LAW IN THE SPACE EPOCH: LAW AND ENVIRONMENT}

*Tymur Korotkyi - PhD in Law, Head of the Department of International Law and Comparative Law, National Aviation University, (1, Liubomyra Huzara Ave, Kyiv, Ukraine).

\section{Abstract}

The article analyses the impact of space activities on the development of international maritime law, namely the institute for freedom of the high seas and the institute for the protection of the marine environment.

The correspondence of the practice of spacecraft burial in the high seas to the freedoms of the high seas and the principle of preserving and protection of the marine environment is investigated. It is concluded that this activity is not prohibited, but it is not included in the normative content of these freedoms.

It is concluded that the flooding of spacecraft on the high seas falls under the obligation to preserve and protect the marine environment in accordance with UNCLOS. When spacecraft are buried, States have obligations that are regulated by Articles 205, 206 of UNCLOS. 
It is justified that the regime of the spacecraft burial in the high seas in an ecological context can be analysed by analogy with the regime established by the 1972 Convention on the Prevention of Marine Pollution by Dumping of Wastes and Other Matter, which, however, does not apply to spacecraft. It is necessary to extend the 1972 Convention to any deliberate removal into the sea of wastes or other materials / burial of spacecraft at sea.

A new type of use of the high seas has been identified, namely launching spacecraft from the high seas, fixed in the form of international legal custom.

It is established that the operation of the marine complex for the transportation and launch of the rocket carrier, should be carried out in accordance with the requirements of UNCLOS. Similarly, the return of launcher also leads to pollution of the marine environment, which requires an appropriate international legal regulation.

It is substantiated that the relations arising in the framework of space exploration activities require complex international legal regulation, with application of the rules of international maritime law, international air law and international space law.

The general conclusion is made about the emergence of a new way of using maritime spaces, which requires the application of already existing international legal norms, their analysis in terms of new relations, and the creation of norms aimed at eliminating gaps that are formed in connection with the implementation of the projects about using Oceans for space activities.

Keywords: Oceans, space activities, marine pollution, marine environment protection and conservation, high seas, UNCLOS, burial of spacecraft, international maritime law.

Міжнародне морське право знаходиться в постійному розвитку під впливом економічних і соціальних потреб, у тому числі обумовлених науково-технічними досягненнями у сфері освоєння морських просторів і ресурсів. Умовно «лінійний» розвиток міжнародного морського права був порушений необхідністю реагування на виникнення авіації, що відбилося в становленні свободи польотів над відкритим морем. Аналогічно, безсумнівно, що розвиток космічної діяльності вплине на розвиток інститутів міжнародного морського права, серед яких інститут свобод відкритого моря та інститут охорони морського середовища. Саме через призму цих інститутів ми розглянемо генезис міжнародного морського права під впливом космічної діяльності.

У вітчизняному науковому дискурсі проблематика впливу космічної діяльності на розвиток міжнародного морського права майже 
відсутня. Це пов'язано з міжгалузевім характером даної проблеми в рамках міжнародного права та їі актуалізацією лише останніми десятиріччями. Серед нечисленних досліджень, на нашу думку, найбільш важливими є праці С. Кричевського, Н. Р. Малишевої , Ю. С. Шемшученко та інших. Отже, метою статті є дослідження генези певних інститутів міжнародного морського права під впливом космічної діяльності та прогнозування змін у міжнародному морському праві під впливом цієї діяльності.

Використання Світового океану з метою освоєння космічного простору є хоча й абсолютно новим видом діяльності, що практично виник $з$ моменту перших запусків космічних апаратів, але отримав «друге дихання» саме у XXI столітті.

На наш погляд, можна виділити декілька видів використання морських просторів, пов'язаних з космічною діяльністю. Це, по-перше, використання Світового океану для захоронення космічних апаратів; по-друге - створення і експлуатація морських суден, пов'язаних з космічною діяльністю; по-третє - це використання морських платформ для запуску космічних апаратів у рамках проекту «Морський старт»; по-четверте - це використання морських суден для запуску й приземлення або приводнення космічних апаратів компанії «SpaceX».

Перебуваючи на межі морського, повітряного і космічного права, істотна специфіка нових відносин вимагає не лише розробки нових норм у рамках чинного міжнародного права, але й особливостей їх застосування (імплементації) по відношенню до існуючих правових інститутів і режимів, серед яких інститут свобод відкритого моря, включаючи свободу польотів над відкритим морем, режими захисту і збереження морського середовища.

Спробуємо надати короткий аналіз кожному з них.

1. 3 початку «космічної ери» морські простори використовувалися для затоплення космічних апаратів - існує певний район Світового океану під грізною назвою «кладовище космічних кораблів» (Точка Немо. Кладбище космических кораблей). Район затоплення виведених із навколоземної орбіти космічних станцій і вантажних кораблів знаходиться у південній частині Тихого океану під координатами $43^{\circ} 34^{\prime} 48^{\prime \prime}$ пд. ш. і 14243'12" зах. Д., вдалині від судноплавних шляхів і населених територій.

Затопленню підлягають станції та кораблі, що виробили свій ресурс, одночасно із завантаженим у їх відсіки різного роду сміттям і відходами життєдіяльності космічних експедицій. Як правило, по- 
верхні води досягають лише тугоплавкі елементи конструкцій, які потім опускаються на глибину близько чотирьох кілометрів. Щорічно в цьому районі затоплюється кілька десятків космічних апаратів. 31971 по 2016 роки в «Точці Немо» захоронено 263 космічних апаратів (Точка Немо. Кладбище космических кораблей).

Найзначніша утилізація космічного апарату мала місце 23 березня 2001 року, коли була затоплена космічна станція «Мир» вагою в 143 тони. Одним із останніх найбільш відомих затоплень стало захоронення китайської орбітальної станщії «Тяньгун-1» 2 квітня 2018 р. Регулярно відбувається затоплення російських вантажних кораблів «Прогрес».

Незважаючи на заяви різних представників космічної галузі про екологічну безпеку такого способу утилізації космічних апаратів, існують певні сумніви у відсутності негативних наслідків для морського середовища.

Така діяльність, безсумнівно, не заборонена міжнародним правом, однак, по-перше, виникає питання про ії співвідношення зі свободою відкритого моря, оскільки мова може йти про обмеження окремих свобод відкритого моря, і по-друге - про порушення такою діяльністю принципу захисту і збереження морського середовища та конкретних норм конвенцій у цій галузі.

Як зазначає Н. Р. Малишева, «...на жаль, міжнародне екологічне й міжнародне космічне право практично не регулюють питання безпечного знищення відповідних об'єктів спалюванням або затопленням. Водночас на рівні ООН дедалі частіше лунають голоси в підтримку ідеї введення міжнародного мораторію на ліквідацію великих космічних об'єктів та їх фрагментів через спалювання в атмосфері Землі та затоплення у Світовому океані, введення відповідних правових заходів, які б стимулювали застосування екологобезпечних технологій на повному життєвому циклі існування великих космічних об'єктів, подібних станції «Мир» чи Міжнародній космічній станції» (Малишева, 2006, с. 29).

Ю. С. Шемшученко, розглядаючи проблему заборони забруднення $з$ космосу в процесі космічної діяльності у рамках міжнародного космічного права, вважає: «...відповідні міжнародно-правові акти приймалися тоді, коли екологічна проблема у зв'язку з космічною діяльністю була скоріше гіпотетичною, ніж практичною. 3 точки зору de lege ferenda, тут слід було б вжити заходів щодо удосконалення правового регулювання як у рамках космічного, так і екологічного права» (Шемшученко, 2007). 
Такий загальний принцип закріплено в положенні Резолюції «Космос на межі тисячоліть: Віденська декларація про космічну діяльність та розвиток людського суспільства»: «v) забезпечення на максимально можливому рівні того, щоб здійснення усіх видів космічної діяльності, особливо тих, які можуть мати згубні екологічні наслідки на місцевому рівні та в глобальних масштабах, зменшувало б такі наслідки, а також для прийняття належних заходів для досягнення такої мети» (Космос на межі тисячоліть: Віденська декларація про космічну діяльність та розвиток людського суспільства. Резолюція третьої Конференщії Організації Об'єднаних Націй з дослідження та використання космічного простору в мирних цілях (ЮНІСПЕЙС-ІІІ) від 30.07.1999 р.).

3 точки зору міжнародного морського права, район «кладовища космічних кораблів» належить до відкритого моря, тобто знаходиться за межами національної юрисдикції. Стосовно відкритого моря діють свободи відкритого моря, перелік яких наведено в ст. 87 Конвенції ООН з морського права 1982 р, і який є вичерпним. 3 одного боку, дана діяльність не $є$ забороненою, але з іншого, вона не включена до переліку зазначених свобод.

Виходячи з переліку свобод відкритого моря, свободи, закріплені ст. 87 Конвенції 1982 р., є пріоритетними. Зокрема виникає питання, наскільки захоронення космічних апаратів у відкритому морі перешкоджає реалізації наведених свобод. Оскільки район «кладовища космічних кораблів» обрано для зазначеної діяльності саме в силу низької інтенсивності судноплавства, зважаючи, що він знаходиться на значній відстані від традиційних судноплавних шляхів, а рибальство в цьому районі $є$ не дуже активним завдяки віддаленості й низькій біологічній продуктивності цієї частини Тихого океану, зазначені свободи не вступають в конкуренцію 3 діяльністю щодо захоронення космічних апаратів. Відносно решти свобод відкритого моря питань поки також не виникає. Однак актуальними залишаються питання захисту та збереження морського середовища.

Згідно загальному зобов' язанню, що міститься в п. 1 ст. 194 Конвенції 1982 р., «Держави... приймають усі сумісні з даною Конвенцією заходи, необхідні для запобігання, скорочення та збереження під контролем забруднення морського середовища з будьякого джерела...» Тобто затоплення космічних апаратів у відкритому морі цілком підпадає під зобов' язання, що міститься в цій статті, тому що не обмежує ані характер джерела забруднення, ані просторову 214 
область Світового океану. У п. 3. зазначеної статті мова так само йде про те, що «...заходи, що вживаються згідно з цією частиною, стосуються всіх джерел забруднення морського середовища». Однак далі, при деталізації цих заходів стосовно конкретних джерел, вказівка на захоронення космічних апаратів відсутня.

Безсумнівно, прямим обов'язком держав стосовно захоронення космічних апаратів є постійний моніторинг за наслідками цієї діяльності, яку вони дозволяють або яку вони здійснюють, з метою визначення, чи може така діяльність призвести до забруднення морського середовища (п. 2 ст. 204 Конвенції 1982 р.). Відповідно, при здійсненні діяльності щодо захоронення космічних апаратів держави зобов' язані виконувати зобов' язання, передбачені в ст. 205 і 206 Конвенції 1982 р.

Затоплення космічних апаратів у відкритому морі підпадає під регламентацію забруднення, викликаного захороненням (ст. 210 Конвенції 1982 р). Це пп. 1, 2, 3, 4, 6 зазначеної статті. Виникає питання про наявність у держав законодавства, застосовного до захоронення космічних апаратів у відкритому морі, і про наявність процедури надання відповідних дозволів на національному рівні.

Режим захоронення космічних апаратів у відкритому морі в екологічному контексті можна аналізувати за аналогією з режимом, встановленим Конвенцією щодо запобігання забрудненню моря скидами відходів та інших матеріалів 1972 р., яка однак не поширюється на космічні апарати. Згідно з Конвенцією 1972 р., під скиданням розуміється «а) і) будь-яке навмисне видалення в море відходів або інших матеріалів з суден, літаків, платформ або інших штучно споруджених у морі конструкцій; ii) будь-яке навмисне захоронення в морі суден, літаків, платформ або інших штучно споруджених у морі конструкцій» (п. 1 ст. ІІІ Конвенції 1972 р.).

3 урахуванням того, що, по-перше, до XXI століття запуск космічних апаратів здійснювався переважно публічними суб'єктами, а по-друге, кількість затоплень космічних апаратів у Світовому океані була відносно незначною, - необхідність міжнародно-правового регулювання цієї діяльності була незначна. Ситуація змінилася у зв'язку 3 комерціалізацією космічної діяльності та виходом на ринок космічних послуг приватних учасників. Як зазначено у преамбулі Резолюції «Космос на межі тисячоліть: Віденська декларація про космічну діяльність та розвиток людського Суспільства», «...суттєві зміни, що відбулися в структурі та змісті всесвітньої космічної діяльності, знаходять 
відображення у зростаючій кількості учасників космічної діяльності на всіх рівнях та в зростаючому внеску приватного сектора в заохочуванні та здійсненні космічної діяльності» (Космос на межі тисячоліть: Віденська декларація про космічну діяльність та розвиток людського суспільства. Резолюція третьої Конференції Організації Об'єднаних Націй з дослідження та використання космічного простору в мирних цілях (ЮНІСПЕЙС-ІІІ) від 30.07.1999 р.). Наведена обставина передбачає необхідність контролю на всіх стадіях такої діяльності, включаючи утилізацію космічних апаратів. Тому має сенс поширити Конвенцію 1972 року і на будь-яке навмисне видалення в море відходів або інших матеріалів / захоронення в море космічних апаратів.

2. Другою формою використання Світового океану з метою освоєння і використання космічного простору стала поява в 60-х роках XX століття суден «морського космічного флоту». У СРСР ці судна, що належали до відання Міністерства оборони СРСР, до 1970 р. ходили під прапором СРСР, та під «легендою» суден постачання рибальського флоту (История СКИ ОМЭР АН СССР, 2016). Тільки 34 листопада 1970 року ці судна отримали статус науково-дослідних, зайнятих у космічних програмах, після створення Служби космічних досліджень при відділі морських експедиційних робіт АН СРСР. Водночас екіпаж суден формувався 3 моряків торгового флоту, а персонал, який здійснював роботи щодо космічних об'єктів і обслуговування технічних засобів, - із офіцерів МО СРСР і цивільних фахівців (История СКИ ОМЭР АН СССР, 2016). На початку 90-х років XX століття використання цих суден стало скорочуватися, а ті, що залишилися, увійшли до складу МО РФ (Распоряжение Правительства РФ от 3 июня 1995 г. № 769-р.). У 1995 р. залишилося чотири судна, які були передані зі складу МО РФ до складу Російського комічного агентства. На сьогоднішній день в РФ існує тільки одне таке судно (История СКИ ОМЭР АН СССР, 2016).

Дані «метаморфози» правового статусу суден «морського космічного флоту» мають більшою мірою вже тільки історичне значення, проте вони цікаві для аналізу.

Звертаючись до Конвенції про відкрите море 1958 р., яка діяла у той період, слід зазначити, що з одного боку «Кожна держава визначає умови надання своєї національності суднам, реєстрації суден на іiі території і права плавати під iї прапором» (ст. 5 Конвенції 1958 р.), тобто СРСР міг досить довільно маніпулювати статусом цих суден. 3 іншого боку, фактично мала місце маніпуляція статусом судна (ста- 
тус військового корабля і статус судна, що належить державі та/або експлуатується нею і знаходиться тільки на некомерційній урядовій службі, відповідно ст. 8, 9 Конвенції 1958 р.), яка проте не приводила до порушення конкретних норм, пов' язаних зі свободою судноплавства у відкритому морі. А в інших просторах - територіальному морі, внутрішніх морських водах і міжнародних протоках, фактично порушувалися або могли порушитись відповідні норми міжнародного і національного права, наприклад, щодо права мирного проходу.

Другим аспектом «перетину» використання морського простору $з$ космічною діяльністю є наявність космічного флоту. 3 точки зору морського права, самі по собі морські судна, які здійснювали спостереження і керування та забезпечували зв'язок 3 космічними апаратами, не були порушенням діючих положень морського права і свободи відкритого моря.

Їх статус як суден, які перебувають на державній некомерційній службі, або належність їх до науково-дослідних суден, не викликав сумнівів. Але до 1970 р. СРСР використовував ці судна «під прикриттям», під статусом допоміжних суден риболовецького флоту, що змінювало правовий режим їх експлуатації й призводило до порушення відповідних норм міжнародного морського права - як стосовно режиму судноплавства в територіальних водах іноземних держав, так і відповідної діяльності у виключних економічних зонах, а також поширення на них положень норм про безпеку судноплавства й охорону морського середовища.

Проблема «космічного флоту» отримує зовсім інший вимір після початку реалізації програм «Морський старт», і особливо програми I. Маска щодо посадки ракети-носія «Falcon» на плаваючу платформу.

3. Третій виклик свободи відкритого моря виник після запуску програми «Морський старт» у 90-ті роки XX століття. Незважаючи на те, що в даний час програма втратила пріоритетність, і їй складають конкуренцію інші проекти, про які йтиметься нижче, однак вона була хронологічно першою щодо запуску космічних апаратів із акваторії Світового океану.

Як уже зазначалося, технічний прогрес призводить до появи нових видів використання відкритого моря, яким є запуск космічних апаратів із акваторії відкритого моря. Переваги «Морського старту» полягають у тому, що запуск ракетоносіїв у районі екватора вимагає меншої кількості енергії, а це дозволяє значно підвищити вагу (в три рази) виведеного в космос (на орбіту) супутника. 
Морський компонент «Морського старту» є комплексом, до складу якого входить плавучий космодром «Одіссей» і судно управління «Sea Launch Commander», яке було спущено на воду в Глазго (Шотландія). Судно було центром управління польотами і плавучим заводом для збірки ракет. 3 судна їх перевантажували на морську платформу, з якої відбувався запуск ракет.

Такі запуски, на наш погляд, призводили до зміни змісту свободи відкритого моря. Перелік свобод відкритого моря, викладений в ст. 87 Конвенції 1982 р., є вичерпним. Тому можна говорити про новий вид використання відкритого моря - запуск космічних апаратів із акваторії відкритого моря. На наш погляд, мова йде про існування самостійної свободи відкритого моря, закріпленої у формі міжнародно-правового звичаю.

4. Четверта група викликів свободі відкритого моря пов'язана 3 програмою Ілона Маска щодо використання Світового океану для запуску і повернення ракет-носіїв, перш за все «Falcon», як безпосередньо на поверхню океану, так і на плавучі платформи. Безсумнівно, з правової точки зору ця діяльність близька до «Морського старту», але має й деякі відмінності, пов'язані з поверненням частин ракетносіїв, а також інші масштаби діяльності.

Космічні апарати й ракети-носії в міжнародному космічному праві належать до космічних об'єктів. Міжнародне космічне право регулює їх діяльність з моменту їх запуску. До цього моменту діяльність щодо ïх створення знаходиться у сфері внутрішньодержавного права, якщо про це немає спеціальної домовленості між державами (наприклад, у разі спільного створення або запуску космічного об'єкта кількома державами). Тому в період транспортування ракети-носія або космічних апаратів їх правовий режим обумовлений законодавством держави, під чиїм прапором плаває це судно, а в період підготовки до запуску і запуску - відповідно юрисдикцією держави прапора керуючого судна та плаваючої платформи.

Використання морських просторів для запуску космічних ракет засновано на принципах свободи відкритого моря, до яких належить свобода судноплавства, свобода польотів і свобода створювати штучні острови та інші установки (ст. 87 розділу I частини VII Конвенції $\mathrm{OOH} з$ морського права). Реалізація наведених свобод здійснюється відповідно до умов, визначених як самою Конвенцією ООН 3 морського права, так і іншими міжнародно-правовими нормами. До них необхідно віднести вимоги з охорони морського середовища від забруднення, дотримання обов' язків держави прапора. 
Правовий статус комплексу обумовлений його функціональною ознакою і приналежністю, що дозволяє охарактеризувати керуюче судно і плаваючу платформу як недержавні судна, які використовується в комерційних цілях.

Під час запуску і повернення ракетоносія відбувається забруднення морського середовища, як це розуміється виходячи з ст. 2 п. 4 Конвенції ООН з морського права. Так, «забруднення морського середовища» означає привнесення людиною, прямо чи опосередковано, речовин або енергії в морське середовище, яке призводить або може призвести до таких згубних наслідків, як шкода живим ресурсам і життю в морі, небезпека для здоров'я людини, створення перешкод для діяльності на морі, в тому числі для рибальства та інших правомірних видів використання моря, зниження якості використовуваної морської води та погіршення умов відпочинку. При цьому діяльність щодо експлуатації комплексу, перш за все плаваючої платформи, має здійснюватися з урахуванням вимог Конвенції 1982 р.

Повернення ступенів ракети-носія також призводить до забруднення морського середовища. Однак, будучи діяльністю правомірною, цей вид забруднення регламентовано Договором про принципи діяльності держав 3 дослідження і використання космічного простору, включаючи Місяць та інші небесні тіла (1967 р.). У ст. IX Договору про космос встановлено зобов' язання проводити вивчення та дослідження космічних просторів, включаючи Місяць та інші небесні тіла, «...таким чином, щоб уникати їх шкідливого забруднення, а також несприятливих змін земного середовища внаслідок доставки».

Слід зазначити, що відносини, які виникають у рамках прогресу освоєння космічного простору, вимагають комплексного міжнародно-правового регулювання, із застосуванням норм міжнародного морського, міжнародного повітряного та міжнародного космічного права.

Саме під впливом цього прогресу, в рамках міжнародного морського права можна говорити про виникнення нового способу використання морських просторів, що вимагає не тільки застосування вже існуючих міжнародно-правових норм та їх аналізу з точки зору появи нових відносин, але й створення / розробку норм, спрямованих на усунення прогалин, які утворюються в зв' язку з реалізацією проектів використання Світового океану, пов'язаних з космічною діяльністю. 


\section{Лiтература:}

История СКИ ОМЭР АН СССР (2016). Научно-исследовательское судно Космонавт Георгий Добровольский. URL: http:/ / niskgd.ru/fleet/index.htm Космос на межі тисячоліть: Віденська декларація про космічну діяльність та розвиток людського суспільства. Резолюція третьої Конференції Організації Об'єднаних Націй 3 дослідження та використання космічного простору в мирних цілях (ЮНІСПЕЙСIII) від 30.07.1999 р. Офіиійний сайт Верховної Ради України. URL: https:/ / zakon.rada.gov.ua/laws/show/995_a27

Малишева, Н. Р. (2006). Правове забезпечення екологічної безпеки космічної діяльності. Юридичний вісник «Повітряне $і$ космічне право», T. 1, 1, 27-30.

Распоряжение Правительства РФ от 3 июня 1995 г. № 769-р.

Точка Немо. Кладбище космических кораблей. Достопримечательности мира. Самые удивительные и красивые места планеты. URL: https:/ / cattur.ru/antarktida/tochka-nemo.html

Шемшученко, Ю. С. (2007). Проблеми розвитку міжнародного космічного права. Науковий вісник Дипломатичної академії України, Випуск 13, 118-122.

\section{References:}

Istoriya SKI OMER AN SSSR (2016) [History of SKI OMER of the USSR Academy of Sciences (2016)]. Nauchno-issledovatelskoye sudno Kosmonavt Georgiy Dobrovolskiy [Research vessel Cosmonaut George Dobrovolsky]. URL: http:/ / niskgd.ru/fleet/index.htm. [in Russian].

Kosmos na mezhi ty`syacholit` Videns`ka deklaraciya pro kosmichnu diyal'nist` ta rozvy`tok lyuds`kogo suspil`stva. Rezolyuciya tret’oyi Konferenciyi Organizaciyi Ob'yednany`x Nacij z doslidzhennya ta vy`kory`stannya kosmichnogo prostoru v my`rny`x cilyax (YuNISPEJSIII) vid 30.07.1999 r. [Cosmos between the thousandths: The Vidensk declaration about space and the development of human suspension. RESOLUTION OF THE THIRD CONFERENCE ORGANIZATION OF NECESSARY NATIONAL ACCOMMODATION]. Oficijny j sajt Verxovnoyi Rady 'Ukrayiny [Ofitsiyny site of the Supreme For the sake of Ukraine]. URL: https://zakon.rada.gov.ua/laws/show/995_a27. [in Ukrainian].

Maly`sheva, N. R. (2006). Pravove zabezpechennya ekologichnoyi bezpeky`kosmichnoyi diyal`nosti [The law provides for the protection of 
environmentally friendly customers]. Yury'dy 'chny j visny`k "Povitryane i kosmichne pravo» [Legal Newsletter "Power and Space Law"], T. 1, 1, 27-30. [in Ukrainian].

Rasporyazheniye Pravitelstva RF ot 3 iyunya 1995 g. № 769-r. [Order of the Government of the Russian Federation of June 3, 1995 No. 769-r. [in Russian].

Shemshuchenko, Yu. S. (2007). Problemy`rozvy`tku mizhnarodnogo kosmichnogo prava [Problems of development of international space law]. Naukovy`j visny`k Dy`plomaty`chnoyi akademiyi Ukrayiny` [Science Newsletter of the Diplomatic Academy of Ukraine], Vy`pusk 13, 118-122. [in Ukrainian].

Tochka Nemo. Kladbishche kosmicheskikh korabley [Point Nemo. Spaceship cemetery. Landmarks of the world]. Dostoprimechatelnosti mira. Samyye udivitelnyye i krasioyye mesta planety [The most amazing and beautiful places on the planet]. URL: https:/ / cattur.ru/antarktida/tochkanemo.html. [in Russian].

\section{Анотація}

Короткий Т.Р. Міжнародне морсъке право в космічну еру: право та екологія. - Стаття.

У статті проаналізовано вплив космічної діяльності на розвиток міжнародного морського права, а саме інституту свобод відкритого моря та інституту охорони морського середовищза.

Досліджено відповідність практики захоронення космічних апаратів у відкритому морі свободам відкритого моря і принцииу збереження та захисту морського середовища. Зроблено висновок, щуо дана діяльність не $є$ забороненою, але не входить в нормативнии зміст зазначених свобод.

Зроблено висновок про те, що затоплення космічних апаратів у віdкритому морі підпадає під зобов'язання про збереження $і$ захист морського середовища відповідно UNCLOS. При здійсненні діяльності з захоронення космічних апаратів держави несуть зобов'язання, передбачені в cm.cm. 205, 206 UNCLOS.

Обгрунтовано, що режим захоронення космічних апаратів у відкритому морі в екологічному контексті можна аналізувати за аналогією з режимом, встановленим Конвенцією щудо запобігання забрудненню моря скидами відходів та інших матеріалів 1972 р., яка, однак, не поширюється на космічні апарати. Необхідно поширити Конвенцію 1972 р. на будь-яке навмисне видалення $b$ море bidходів або інших матеріалів / захоронення в море космічних апаратів. 
Виділено новий вид використання відкритого моря - запуск космічних апаратів з відкритого моря, закріплений у формі міжнародно-правового звичаю.

Встановлено, що діяльність по експлуатації морського комплексу з транспортування і запуску ракетоносія, має здійснюватися з урахуванням вимог UNCLOS. Аналогічно, повернення ступенів ракети-носія також призводить до забруднення морського середовища, щзо вимагає відповідної міжнародноправової регламентації.

Обгрунтовано, що відносини, що виникають в рамках діяльності з освоєння космічного простору, Вимагають комплексного міжнародно-правового регулювання, із застосуванням норм міжнародного морського, міжнародного повітряного і міжнародного космічного права.

Зроблено загальний висновок про виникнення нового способу використання морських просторів, щуо Вимагає застосування як Вже існуючих міжнародно-правових норм, їх аналізу з точки зору нових відносин, так i створення норм, спрямованих на усунення прогалин, що утворюються в зи'язку з реалізацією проектів використання Світового океану з метою космічної діяльності.

Ключові слова: Світовий океан, космічна діяльність, забруднення морського середовища, захист і збереження морського середовища, відкрите море, UNCLOS, поховання космічних апаратів, міжнародне морське право. 